\title{
Whey Isolation from Rejected Human Milk and Its Lipid Content Characterization by GC-FID and ESI-MS
}

\author{
Eloize S. Alves, ${ }^{a}$ Matheus C. Castro, ${ }^{\circ b}$ Bruno H. F. Saqueti, ${ }^{a}$ Luciana P. Manin, ${ }^{\circ} a$ \\ Roberta da Silveira, ${ }^{\oplus a}$ Patrícia M. Souza, ${ }^{b}$ Oscar O. Santos ${ }^{\oplus b}$ and Jesuí V. Visentainer ${ }^{\circledR} * a$ \\ ${ }^{a}$ Programa de Pós-Graduação em Ciência de Alimentos, Universidade Estadual de Maringá, \\ 87020-900 Maringá-PR, Brazil \\ ${ }^{b}$ Departamento de Química, Universidade Estadual de Maringá, \\ 87020-900 Maringá-PR, Brazil
}

\begin{abstract}
The present work intends to obtain and characterize a milk by-product: the human whey (HW), in order to avoid the excessive disposal of human milk (HM). The characterization was performed through analyzes of the chemical composition and fatty acids (FAs) and the triacylglycerol (TAG) lipid profile. The results indicated that the chemical composition altered significantly after the HW obtained, except for the percentage of ash and carbohydrates. About the FA composition, it was observed that strictly essential FA, essential FA and other FAs found in HM remained present in HW. For the nutritional lipids quality, the atherogenicity and the thrombogenicity indices presented desirable values, and the TAGs lipid profile revealed a variation in the analyzed samples. Therefore, it can be concluded that the characterized HW has potential for application in isolated form or to be used as an ingredient in other foods.
\end{abstract}

Keywords: human milk, human whey, GC-FID, fatty acids, ESI-MS, triacylglycerol

\section{Introduction}

According to definition, milk originates from the mammary gland of female mammals. It is the primary food source for newborns, plus it supports in the organism's development and the human survival. ${ }^{1}$ The human milk (HM) must be the exclusive food source during the infants' first six months of life, and if breastfeeding is interrupted by some factor (hypogalactia or pre-existing illnesses in the lactating mother), the American Academy of Pediatrics recommends the use of donated pasteurized human milk. ${ }^{2}$

In order to meet this demand, human milk banks were created. This service ensures a safe product, free from pathogenic microorganisms, based on collection, processing, quality control and distribution. ${ }^{3}$ The HM quality supplied to human milk banks is the result of hygienic conditions, from milking to administration. Consequently, several parameters are evaluated, such as nutritional, chemical and microbiological characteristics. ${ }^{4}$

As stipulated in the Resolution of the Collegiate Board/ Agência Nacional de Vigilância Sanitária (RDC/ANVISA)

*e-mail: jesuivv@gmail.com
No. $222 / 2018,{ }^{5}$ the HM that does not meet the specifications, must be directly disposed in the sewage system. The work of Grazziotin et al. ${ }^{6}$ on the HM disposal donated to a human milk bank, reports that this volume is approximately 10.5 to $24.0 \%$ of the total received, with mature milk (HM with more than 15 days postpartum) of greater volume collected and discarded in the research. In 2019, all Brazilian states presented production reports based on statistical data, provided by the database of the Brazilian network of human milk banks, which exposes an average disposal of 20.0 to $30.0 \% .^{7}$ The authors are not aware of any work that reuses this residual milk for the development of co-products and studies on this development will be promissory.

Whey is a milk derivative, light yellow to greenish color, composed of lactose, soluble proteins, vitamins, lipids and minerals. ${ }^{8}$ It can be obtained from the separation/ sedimentation of casein from serum milk proteins, by centrifugation ${ }^{9}$ or ultracentrifugation. ${ }^{10}$

Among its extensive benefits, human whey (HW) has high concentrations of proteins and bioactive components, which are complement system proteins, regulatory proteins and antimicrobial proteins; responsible for the 
mucosal immune response and it also guarantees the growth and development of newborns. ${ }^{10}$ Furthermore, Gomes-Santos et al. ${ }^{11}$ showed in their results that the consumption of protein present in bovine serum was capable to prevent signs of inflammation and changes in immunological characteristics typical of food allergy pathology. The authors did not find in the literature reports that involves the lipid profile of HW or its fatty acids (FAs) composition.

Therefore, in order to prevent the disposal of this product, and in an attempt to apply it to infant feeding, the objective of this work was to characterize human whey derived from discarded human milk, due to dirt, from the human milk bank of Maringá (Paraná, Brazil), using analysis of fatty acids (FA) composition, triacylglycerol (TAG) lipid profile and proximate composition.

\section{Experimental}

Sampling

This study was approved by the Research Ethics Committee (REC), number 2.797.476, of the Universidade Estadual de Maringá (UEM, Maringá, Paraná, Brazil). Samples of raw mature human milk (HM) discarded due to dirt (example: hair, eyelashes) were collected at cooling temperature of $4{ }^{\circ} \mathrm{C}$, at the human milk bank of the Hospital Universitário de Maringá (Maringá, Paraná, Brazil). Subsequently, the HM was homogenized and pooled with 15 donors, obtaining a final volume of 3.0 liters. The sample was divided into 1.0 liter for further analysis and 2.0 liters to obtain the human whey (HW). It was packed in hermetic polyethylene packages and stored at $-18{ }^{\circ} \mathrm{C}$ for further development and analysis of the HW.

\section{Reagents}

Chloroform, $n$-heptane, methanol and sodium chloride (all analytical grade) were purchased from Synth (São Paulo, Brazil). Sodium hydroxide, ammonium chloride and sulfuric acid (all analytical grade) were purchased from Dinâmica (São Paulo, Brazil). Methanol and chloroform (high performance liquid chromatography (HPLC) grade) were purchased from J.T. Baker ${ }^{\circledR}$ (Philipsburg, United States) and Riedel-de Haën (Seelze, Lower Saxony, Germany), respectively. Ammonium formate $(97 \%)$ was purchased from Sigma-Aldrich (Darmstadt, Germany). For gas chromatographic (GC) analysis, the reagents and solvents used were analytical grade and for mass spectrometry (MS) analysis, the solvents were HPLC grade.

\section{Human whey (HW) obtainment}

Human whey (HW) was obtained according to Lu et al. $;^{10} 2.0$ liters of the HM were centrifuged at $1500 \mathrm{~g}$ for $10 \mathrm{~min}$ at temperature of $10{ }^{\circ} \mathrm{C}$ in order to remove the fat layer. Skimmed HM was ultracentrifuged at $6000 \mathrm{~g}$ for $30 \mathrm{~min}$ at temperature of $30^{\circ} \mathrm{C}$ in order to sediment the casein. The HW was obtained by filtration after the aforementioned centrifugation, thus removing dirt and sedimented casein, being then homogenized, in a final volume of 1.8 liters, and stored in vacuum-sealed polyethylene package, subjected to freezing at temperature of $-18{ }^{\circ} \mathrm{C}$. The obtainment of the $\mathrm{HW}$ is described in Figure 1.

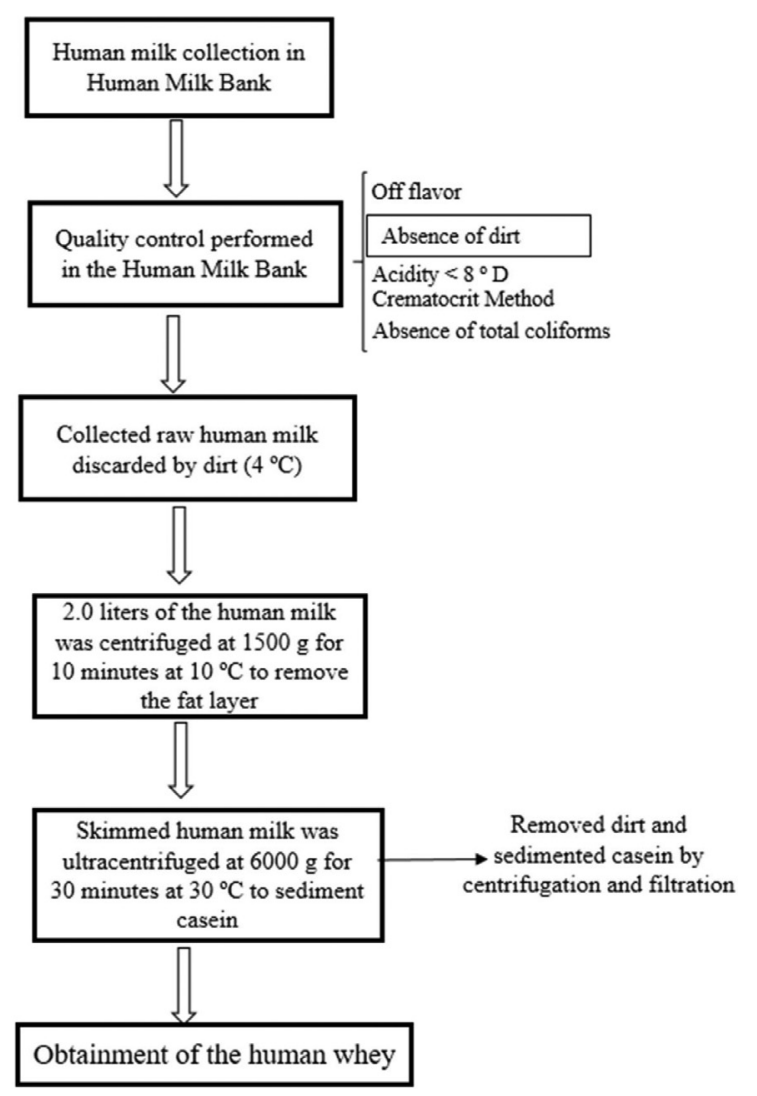

Figure 1. Process for the obtainment of the human whey.

\section{Assessment of proximate composition}

The analyzes of moisture (method 934.01), ash (method 942.05), proteins (method 990.03) and carbohydrates by calculating the difference, were performed according to the Association of Official Analytical Chemists (AOAC). ${ }^{12}$ The lipid content was determined according to the methodology of Folch et al..$^{13}$ The energy value of food was expressed by the sum of macronutrients that compose it, using the nutrient conversion factors that potentially provide 
energy for the human body, such as lipids, carbohydrates and proteins. Each gram of carbohydrate corresponds to $4 \mathrm{kcal} \mathrm{g}^{-1}$ (or $17 \mathrm{~kJ} \mathrm{~g}^{-1}$ ), proteins to $4 \mathrm{kcal} \mathrm{g}^{-1}$ ( or $17 \mathrm{~kJ} \mathrm{~g}^{-1}$ ) and fat to $9 \mathrm{kcal} \mathrm{g}^{-1}$ (or $37 \mathrm{~kJ} \mathrm{~g}^{-1}$ ). ${ }^{14}$

\section{Fatty acid (FA) composition}

The HW lipid sample were extracted according to Folch et al., ${ }^{13}$ then the fatty acid methyl esters (FAMEs) were prepared by methylation of the total lipids according to International Organization for Standardization (ISO) 12966:2017. ${ }^{15}$ The upper phase was collected with the assistance of a Pasteur pipette, transferred to a vial and analyzed in a GC (Trace Ultra 3300, Waltham, United States) with flame ionization detector (FID), capillary column CP-7420 (100.0 m size, $0.25 \mathrm{~mm}$ internal diameter and $0.25 \mu \mathrm{m}$ cyanopropyl thin film as stationary phase) and split/splitless injector. Detector and injector temperatures were 250 and $230{ }^{\circ} \mathrm{C}$, respectively. The gas chromatography-flame ionization detector (GC-FID) oven was set at temperature of $65^{\circ} \mathrm{C}$ and maintained for $4 \mathrm{~min}$, then heated to the temperature of $185^{\circ} \mathrm{C}$ to $15^{\circ} \mathrm{C} \mathrm{min}{ }^{-1}$ and maintained for $12 \mathrm{~min}$, then heated again to the temperature of $235{ }^{\circ} \mathrm{C}$ to $20{ }^{\circ} \mathrm{C} \mathrm{min}{ }^{-1}$ and maintained for $14 \mathrm{~min}$. The gas flow used were: $1.4 \mathrm{~mL} \mathrm{~min}^{-1}$ for carrier gas $\left(\mathrm{H}_{2}\right), 30 \mathrm{~mL} \mathrm{m^{-1 }}$ for replacement gas $\left(\mathrm{N}_{2}\right)$ and 30 and $300 \mathrm{~mL} \mathrm{~min}^{-1}$ for gas flames $\left(\mathrm{H}_{2}\right.$ and synthetic air, respectively). The split injection mode was used with a ratio of 1:100 and the sample injection volume was $2.0 \mu \mathrm{L} .{ }^{16}$ FAMEs were identified by comparison in the retention times of the constituent samples with the analytical standards (standard mixture FAME, C4-C24, Sigma-Aldrich, Saint Louis, United States). Peak areas were determined using the ChromQuest ${ }^{\mathrm{TM}} 5.0$ software and the FA compositions were expressed as relative area percentage. All samples were analyzed in triplicate.

\section{Nutritional lipid quality}

Nutritional quality was assessed by 6 indices: atherogenicity index (AI) (equation 1), thrombogenicity index (TI) (equation 2) and proportion of FA hypocholesterolemic/hypercholesterolemic $(\mathrm{H} / \mathrm{H})$ (equation 3), ${ }^{17,18}$ sum of omega-6 family due to omega-3 family (equation 4), sum of polyunsaturated fatty acids (PUFA) due to sum of saturated fatty acids (SFA) (equation 5), and sum of eicosapentaenoic (EPA) FA and docosahexaenoic (DHA) FA (equation 6). The values were submitted by the equations 1-6, and all concentrations are in relative area percentage.
$\mathrm{AI}=\frac{[12: 0+(4 \times 14: 0)+16: 0]}{\text { MUFA }+\mathrm{n}-6+\mathrm{n}-3}$

$\mathrm{TI}=\frac{(14: 0+16: 0+18: 0)}{\left[(0.5 \times \text { MUFA })+(0.5 \times \mathrm{n}-6)+(3 \times \mathrm{n}-3)+\left(\frac{\mathrm{n}-3}{\mathrm{n}-6}\right)\right]}$

$\mathrm{H} / \mathrm{H}=\frac{[(18: \ln -9+18: 2 \mathrm{n}-6+18: 3 \mathrm{n}-3+20: 3 \mathrm{n}-6+20: 4 \mathrm{n}-6+20: 5 \mathrm{n}-3+22: 6 \mathrm{n}-3)]}{(12: 0+14: 0+16: 0)}$

Proportion of omega family $=\frac{\Sigma[\mathrm{n}-6]}{\Sigma[\mathrm{n}-3]}$

Proportion of polyunsaturated and saturared fatty acids $=\frac{\Sigma[\text { PUFA }]}{\Sigma[\text { SFA }]}$

Sum of essential fatty acids $=$ EPA + DHA

where MUFA is monounsaturated fatty acids.

\section{Triacylglycerol (TAG) profile}

The TAG profile was obtained by direct infusion in mass spectrometry (MS) using an electrospray ionization (ESI) source. HW lipid samples were prepared according to da Silveira et al. $;^{19}$ approximately $50.0 \mu \mathrm{L}$ of lipid was added to $950.0 \mu \mathrm{L}$ of chloroform. $5.0 \mu \mathrm{L}$ of this solution was transferred to a vial and $1.0 \mathrm{~mL}$ of $9: 1$ methanol/ chloroform solution $\left(\mathrm{v} \mathrm{v}^{-1}\right)$ was added. In order to obtain the ammonium adducts [TAG $\left.+\mathrm{NH}_{4}\right]^{+}, 20.0 \mu \mathrm{L}$ of $0.10 \mathrm{~mol} \mathrm{~L}^{-1}$ ammonium formate prepared in methanol were added to the final solution. The prepared solutions were infused with a flow of $10.0 \mu \mathrm{L} \mathrm{min}{ }^{-1}$ directly into a Xevo TQ-D ${ }^{\mathrm{TM}}$ triple quadrupole MS (Waters, Milford, Massachusetts, United States) equipped with $\mathrm{Z}$ spray ${ }^{\mathrm{TM}} \mathrm{ESI}$, operating in positive mode (ESI+), conditions as follows: desolvation gas flow $\left(500 \mathrm{~L} \mathrm{~h}^{-1}\right)$, source temperature $\left(150{ }^{\circ} \mathrm{C}\right)$, desolvation temperature $\left(200{ }^{\circ} \mathrm{C}\right)$ and capillary and cone voltages (3.00 kV and $20.00 \mathrm{~V}$, respectively). The HW TAG profile was evaluated in the mass range of $\mathrm{m} / \mathrm{z}$ 530-1100. The results obtained were determined using the MassLynx ${ }^{\mathrm{TM}}$ software.

\section{TAG assignment and estimation}

TAGs were assigned and estimated (\%) using the LAMES Platform, which is based on the mathematical algorithm that describes the distribution of FA in TAG molecule ${ }^{20}$ using the FA percentage determined by GC-FID. With the Lipid maps ${ }^{\circledR}$ database, it was possible to discover the molecular formula of the TAGs. 


\section{Statistical analysis}

Data from all analyzes were submitted to analysis of variance (ANOVA) and Tukey's test $(p<0.05)$, using the software Assistat version 7.7. ${ }^{21}$

\section{Results and Discussion}

Yield and applications

The yield of the developed product is approximately $90 \%$, that is, for one liter of HM, it is possible to obtain near $900 \mathrm{~mL}$ of HW. HW is a product that can be applied in isolation, only in the HM, or also to benefit other products, such as yoghurts, dairy drinks, among others. ${ }^{22}$

\section{Centesimal composition}

Table 1 describes the results of the centesimal composition ( $\mathrm{g}$ per $100 \mathrm{~mL}$ ) and the calculated energy value (kcal per $100 \mathrm{~mL}$ ) of human milk (HM) and human whey (HW).

Table 1. Centesimal composition and energy value of human milk (HM) and human whey (HW)

\begin{tabular}{lcc}
\hline Analysis & HM & HW \\
\hline Moisture / $(\mathrm{g}$ per $100 \mathrm{~mL})$ & $89.11 \pm 0.13^{\mathrm{b}}$ & $91.56 \pm 0.07^{\mathrm{a}}$ \\
Ash / (g per $100 \mathrm{~mL})$ & $0.15 \pm 0.01^{\mathrm{a}}$ & $0.15 \pm 0.02^{\mathrm{a}}$ \\
Protein / (g per $100 \mathrm{~mL})$ & $1.29 \pm 0.10^{\mathrm{a}}$ & $1.12 \pm 0.05^{\mathrm{a}}$ \\
Total lipid / (g per $100 \mathrm{~mL})$ & $3.23 \pm 0.13^{\mathrm{a}}$ & $0.93 \pm 0.13^{\mathrm{b}}$ \\
Carbohydrate / (g per $100 \mathrm{~mL})$ & $6.22 \pm 0.23^{\mathrm{a}}$ & $6.24 \pm 0.20^{\mathrm{a}}$ \\
Energetic value / (kcal per $100 \mathrm{~mL})$ & $59.10 \pm 0.32^{\mathrm{a}}$ & $37.80 \pm 0.31^{\mathrm{b}}$ \\
\hline
\end{tabular}

Results expressed as mean \pm standard deviation (SD) of triplicate. Values with different letters on the same line are significantly different $(p<0.05)$ by the Tukey's test.

Food moisture is related to its stability and quality. In this analysis, the samples showed significantly different values according to the Tukey's test $(p<0.05)$. The sample with the highest moisture was HW $(91.56 \pm 0.07)$, while HM had a value of $89.11 \pm 0.13$; the $\mathrm{HW}$ value is due to the removal of solid matter (fat and protein) from HM during skimming. The values found for HM moisture are values already reported by other researchers for $\mathrm{HM},{ }^{23,24}$ while for $\mathrm{HW}$ the moisture value increased by skimming and casein treatment. ${ }^{25}$

The ash percentage indicates the total amount of minerals present in the food. ${ }^{26}$ Statistically, both samples, $\mathrm{HM}(0.15 \pm 0.01)$ and HW $(0.15 \pm 0.02)$, did not present significant differences between it, as both have the same amount of minerals. The data show similar values because minerals are water-soluble.
For total protein content there was no significant difference between samples. HM sample presented a value of $1.29 \pm 0.10$, that corroborates with the work of Bruxel and Sica, ${ }^{27}$ who mentions that the average HM protein is $1.2 \mathrm{~g}$ per $100 \mathrm{~mL}$. In the HW sample, there was a decrease in protein concentration $(1.12 \pm 0.05)$, due to casein precipitation, which caused a reduction in the amount of total crude protein. According to the literature, the proportion of total protein is divided into $20 \%$ casein and $80 \%$ serum proteins in the first 2 weeks postpartum, and $35 \%$ casein and $65 \%$ serum protein in mature milk. ${ }^{28}$

As for lipids, the samples revealed significantly different values, a higher value for the HM (3.23 \pm 0.13$)$ compared to the HW $(0.93 \pm 0.13)$ samples was already expected due to the skimming process to obtain the HW. The HM sample presented a value close to that found by Rydlewski et al., ${ }^{29}$ which was $3.08 \pm 0.73$ in the HM analysis of the mature lactation phase.

Carbohydrate values were obtained by calculating the difference in macronutrients, that is, these values are influenced by the results obtained in the analysis of moisture, ash, proteins and lipids. Consequently, the carbohydrate values did not indicate significant difference between samples, being HM (6.22 \pm 0.23$)$ and HW $(6.24 \pm 0.20)$.

In evaluating the energy value, there were losses of the total value, due to the loss of lipids and proteins during the obtainment of the HW. HM revealed a value of $59.10 \pm 0.32$, while $\mathrm{HW}$ revealed a value of $37.80 \pm 0.31$. As, for consumption, the minimum amount recommended for feeding infants by Resolution of the Collegiate Board (RDC) $171 / 2006$ is $25 \mathrm{kcal}$ per $100 \mathrm{~mL},{ }^{30}$ all results were superior than required.

\section{Fatty acid (FA) composition by GC-FID}

Table 2 describes the FA composition as relative area percentage $(\%)$ in human milk (HM) and human whey (HW).

As can be observed in Table 2, 32 FAs were identified by the GC-FID. The FA composition originates from the lactating woman's diet, and there may be changes in its concentrations. ${ }^{31}$

Among the FA analyzed, oleic acid (O, 18:1n-9) was the majority for both samples; HM $(31.32 \pm 0.49)$ and HW $(32.28 \pm 0.42)$. Manin et al. ${ }^{32}$ performed the FA determination in HM samples and also obtained 18:1n-9 as the majority, with similar values $(29.47 \pm 0.75)$. Therefore, it can be considered that the results found in this work are within the expected. Oleic acid is used by infant mainly as energy source, in addition to promote the fat absorption 
Table 2. Fatty acid (FA) composition of human milk (HM) and human whey (HW)

\begin{tabular}{|c|c|c|c|}
\hline FA composition & Chemical name & HM & HW \\
\hline $4: 0 / \%$ & butyric acid & $0.40 \pm 0.00^{\mathrm{a}}$ & $0.30 \pm 0.04^{b}$ \\
\hline $6: 0 / \%$ & caproic acid & $0.02 \pm 0.00^{\mathrm{b}}$ & $0.20 \pm 0.03^{\mathrm{a}}$ \\
\hline $8: 0 / \%$ & caprylic acid & $0.07 \pm 0.01^{\mathrm{b}}$ & $0.74 \pm 0.15^{\mathrm{a}}$ \\
\hline $10: 0 / \%$ & capric acid & $1.43 \pm 0.20^{\mathrm{a}}$ & $0.34 \pm 0.01^{\mathrm{b}}$ \\
\hline $12: 0 / \%$ & lauric acid & $6.39 \pm 0.38^{\mathrm{a}}$ & $1.88 \pm 0.19^{\mathrm{b}}$ \\
\hline $14: 0 / \%$ & myristic acid & $6.66 \pm 0.15^{\mathrm{a}}$ & $4.05 \pm 0.08^{\mathrm{b}}$ \\
\hline $14: 1 n-9 / \%$ & myristoleic acid & $0.07 \pm 0.01^{\mathrm{a}}$ & $0.05 \pm 0.00^{\mathrm{b}}$ \\
\hline $15: 0 / \%$ & pentadecyl acid & $0.27 \pm 0.00^{\mathrm{a}}$ & $0.22 \pm 0.00^{\mathrm{b}}$ \\
\hline $16: 0 / \%$ & palmitic acid & $22.24 \pm 0.08^{b}$ & $28.09 \pm 0.78^{\mathrm{a}}$ \\
\hline $16: 1 n-9 / \%$ & hexadecenoic acid & $1.54 \pm 0.11^{\mathrm{a}}$ & $1.70 \pm 0.07^{\mathrm{a}}$ \\
\hline $16: 1 n-7 / \%$ & palmitoleic acid & $0.21 \pm 0.03^{\mathrm{b}}$ & $0.45 \pm 0.03^{\mathrm{a}}$ \\
\hline $17: 0 / \%$ & margaric acid & $0.26 \pm 0.02^{\mathrm{b}}$ & $0.36 \pm 0.02^{\mathrm{a}}$ \\
\hline $17: 1 n-9 / \%$ & trans-10-heptadecenoic acid & $0.19 \pm 0.01^{\mathrm{a}}$ & $0.05 \pm 0.00^{\mathrm{b}}$ \\
\hline $18: 0 / \%$ & stearic acid & $5.65 \pm 0.17^{\mathrm{b}}$ & $10.90 \pm 0.47^{\mathrm{a}}$ \\
\hline $18: \ln -9 / \%$ & oleic acid & $31.32 \pm 0.49^{\mathrm{a}}$ & $32.28 \pm 0.42^{\mathrm{a}}$ \\
\hline $18: 1 n-7 / \%$ & vaccenic acid & $0.05 \pm 0.00^{\mathrm{b}}$ & $1.97 \pm 0.19^{\mathrm{a}}$ \\
\hline $18: 2 n-6 / \%$ & linoleic acid & $20.25 \pm 0.04^{\mathrm{a}}$ & $9.85 \pm 0.13^{\mathrm{b}}$ \\
\hline $18: 2 \mathrm{n}-6 \mathrm{C} 9, \mathrm{t} 11 / \%$ & conjugated linoleic acid & $0.09 \pm 0.00^{\mathrm{b}}$ & $0.27 \pm 0.02^{\mathrm{a}}$ \\
\hline $18: 2 \mathrm{n}-6 \mathrm{t} 10, \mathrm{C} 12 / \%$ & conjugated linoleic acid & $0.11 \pm 0.01^{\mathrm{a}}$ & $0.08 \pm 0.00^{\mathrm{b}}$ \\
\hline $18: 3 n-3 / \%$ & $\alpha$-linolenic acid & $1.08 \pm 0.03^{\mathrm{a}}$ & $0.31 \pm 0.01^{\mathrm{b}}$ \\
\hline $18: 3 n-6 / \%$ & $\gamma$-linolenic acid & $0.09 \pm 0.00^{\mathrm{b}}$ & $0.21 \pm 0.04^{\mathrm{a}}$ \\
\hline $20: 0 / \%$ & arachidic acid & $0.08 \pm 0.01^{\mathrm{b}}$ & $0.11 \pm 0.01^{\mathrm{a}}$ \\
\hline $20: 1 n-9 / \%$ & eicosenoic acid & $0.23 \pm 0.02^{\mathrm{a}}$ & $0.20 \pm 0.00^{\mathrm{a}}$ \\
\hline $20: 3 n-6 / \%$ & di-homo- $\gamma$-linolenic acid & $0.21 \pm 0.04^{\mathrm{a}}$ & $0.20 \pm 0.00^{\mathrm{a}}$ \\
\hline $20: 3 n-3 / \%$ & di-homo- $\alpha$-linolenic acid & $0.31 \pm 0.02^{\mathrm{b}}$ & $0.98 \pm 0.18^{\mathrm{a}}$ \\
\hline $20: 4 n-6 / \%$ & arachidonic acid & $0.06 \pm 0.02^{\mathrm{b}}$ & $0.95 \pm 0.11^{\mathrm{a}}$ \\
\hline $22: 0 / \%$ & behenic acid & $0.08 \pm 0.01^{\mathrm{b}}$ & $1.95 \pm 0.25^{\mathrm{a}}$ \\
\hline $20: 5 n-3 / \%$ & eicosapentaenoic acid & $0.04 \pm 0.00^{\mathrm{b}}$ & $0.36 \pm 0.07^{\mathrm{a}}$ \\
\hline $22: 1 n-9 / \%$ & eruric acid & $0.27 \pm 0.03^{\mathrm{a}}$ & $0.21 \pm 0.01^{\mathrm{b}}$ \\
\hline $24: 0 / \%$ & lignoceric acid & $0.05 \pm 0.00^{\mathrm{b}}$ & $0.21 \pm 0.03^{\mathrm{a}}$ \\
\hline $24: 1 n-9 / \%$ & nerve acid & $0.11 \pm 0.01^{\mathrm{a}}$ & $0.11 \pm 0.01^{\mathrm{a}}$ \\
\hline $22: 6 n-3 / \%$ & docosahexaenoic acid & $0.16 \pm 0.02^{\mathrm{b}}$ & $0.37 \pm 0.06^{\mathrm{a}}$ \\
\hline$\overline{\Sigma(\mathrm{n}-3) / \%}$ & omega 3 & $1.60 \pm 0.02^{\mathrm{b}}$ & $2.01 \pm 0.34^{\mathrm{a}}$ \\
\hline$\Sigma(\mathrm{n}-6) / \%$ & omega 6 & $20.83 \pm 0.02^{\mathrm{a}}$ & $11.62 \pm 0.03^{b}$ \\
\hline$\Sigma \mathrm{SFA} / \%$ & saturated fatty acids & $43.58 \pm 0.47^{\mathrm{b}}$ & $49.34 \pm 0.49^{\mathrm{a}}$ \\
\hline$\Sigma$ MUFA / \% & monounsaturated fatty acids & $33.99 \pm 0.43^{\mathrm{b}}$ & $37.03 \pm 0.17^{\mathrm{a}}$ \\
\hline इPUFA / \% & polyunsaturated fatty acids & $22.43 \pm 0.04^{\mathrm{a}}$ & $13.64 \pm 0.32^{b}$ \\
\hline
\end{tabular}

Results expressed as mean \pm standard deviation (SD) of triplicate. Values with different letters on the same line are significantly different $(p<0.05)$ by the Tukey's test. SFA: saturated fatty acids; MUFA: monounsaturated fatty acids; PUFA: polyunsaturated fatty acids.

from the small intestine. It also composes the membrane structure, as well as the myelination of axons..$^{33,34}$

For the second highest concentration found, there is the palmitic acid (P, 16:0), with HW (28.09 \pm 0.78$)$ and HM $(22.24 \pm 0.08)$. Saturated FA $(\mathrm{P}, 16: 0)$ plays an important role for the infant, such as, the improvement of intestinal discomfort, colic reduction, as well as the influence on the levels of anadamide that has analgesic effect. These benefits are related to the central position that this FA occupies in the TAG molecule, about $70 \%$ of the palmitic acid in HM is in this position, being easily absorbed by the body. ${ }^{31,35}$

For polyunsaturated fatty acids (PUFAs), linoleic acid (L, 18:2n-6) was identified in greater quantity. It is considered a strictly essential FA and a precursor of arachidonic acid (AA, 20:4n-6), which was also found in the samples. Others long-chain PUFAs were also obtained, such as, $\alpha$-linolenic acid (aLn, 18:3n-3), which is a precursor of eicosapentaenoic (EPA, 20:5n-3) and docosahexaenoic (DHA, 22:6n- 3) FAs. In humans, linoleic and $\alpha$-linolenic FAs are necessary to maintain, under normal conditions, cell membranes and brain functions. It also participates in the transfer of atmospheric oxygen to blood plasma, hemoglobin synthesis and cell division. ${ }^{36}$ These essential FAs (AA, EPA, DHA) have crucial functions in the newborn's cognitive, visual, cerebral and immune development. Furthermore, it also protects against allergy, asthma, reduces inflammation rates and childhood obesity. ${ }^{37}$ 
Therefore, both HM and HW maintain the essential FAs, and its precursors, the strictly essential FAs. However, it is important to note that the essential FA content increased in the co-product, for these three essential FAs (AA, 20:4n-6; EPA, 20:5n-3; DHA, 22:6n-3) the increase was significant, being: 1500,900 and $230 \%$, respectively.

FA C9,t11 and t10,C12, which are named conjugated linoleic acid, remained present in all samples. Once the HW was obtained, an increase in C9,t11 and a decrease in $\mathrm{t} 10, \mathrm{C} 12$ were identified, with statistical difference. This FA class is of great importance, as it is associated with several benefits, such as reduced body fat, immune system modulation, improvement in bone mineralization, antidiabetic and anticarcinogenic effects. ${ }^{37}$

HW sample had the highest level of the sum of saturated fatty acids ( $\Sigma$ SFA) $(49.34 \pm 0.49)$, compared to the HM sample $(43.58 \pm 0.47)$. The longest SFA represents the circulating oxidation pool. Stearic acid (S, 18:0) can be rapidly converted to oleic acid, and this pathway indicates the strict metabolic interrelationships between SFA and MUFA, respectively. ${ }^{38}$

For the sum of monounsaturated fatty acids ( $\Sigma$ MUFA), the HW sample was predominant, with a value of $37.03 \pm 0.17 \%$. Finally, for the sum of polyunsaturated fatty acids ( $\Sigma$ PUFA), the HM sample stood out, with a result of $22.43 \pm 0.04 \%$.

In order to compare the HW, HM and infant formulas available on the market, Table 3 exposes its main FAs, which are: 18:2n-6 (LA), 18:3n-3 (ALA), 20:4n-6 (AA), 20:5n-3 (EPA) and 22:6n-3 (DHA). The last three PUFAs mentioned are crucial for the growth regulation, for inflammatory responses, immune function, in addition to playing a fundamental role in the structure and function of neural tissue, in the cell membrane structure, and in the development of the cognitive and motor systems in newborns, ${ }^{39}$ as already mentioned above.

AA and DHA rapidly accumulate in the fetal retina and brain during the last trimester of pregnancy, continuing until the age of two. However, the synthesis of AA and DHA from its precursors LA and ALA is limited in the fetus and neonate due to premature enzymatic activity. For this reason, a correct mother's diet is important to provide these essential FAs first to the fetus and then to the newborn through the HM. ${ }^{40}$

It is also important to note that HM is almost always adequate in essential nutrients, even when mothers' nutrition is inadequate. ${ }^{41}$ Therefore, HM is considered the ideal food, providing lipids that acts as $40-50 \%$ of the energy necessary by the babies, in addition to providing the aforementioned essential FAs and long-chain PUFAs. ${ }^{42}$

Among the PUFAs, the most important to be cited are ARA and DHA, which present significant effects on visual and cognitive development and on neurodevelopment of full-term babies. ${ }^{43}$

From the point of view of the FAs composition, the main ones are oleic acid (OA, 25-35\%), palmitic acid (PA, 20-30\%) and linoleic acid (LA, 10-20\%), whereas from the point of view of the FAs distribution, SFA are predominantly located in the Sn-2 position, and unsaturated FAs are predominantly located in the $\mathrm{Sn}-1,3$ positions. ${ }^{44}$

The FAs composition and the TAGs profile has received a lot of attention in recent years. The composition of FAs and Sn-2 FAs, and the TAGs profile were analyzed in: vegetable oil formula, ${ }^{43}$ cow's milk formula,${ }^{45}$ and goat's milk formula. ${ }^{42}$ The FA composition in infant formulas on the Spanish market was also analyzed and compared with $\mathrm{HM},{ }^{46}$ as well as the TAG profile of infant formulas imported into the Chinese market. ${ }^{47}$

According to Table 3, we can observe similarities, since these dairy products are designed to imitate HM as close as possible, but its composition is relatively constant, whereas HM is a living, non-static fluid, or uniform and adapted to the baby's requirements at each stage. Energy, proteins, lipids and even amino acids and other special components (iron, selenium, nucleotides, prebiotics, probiotics) are controlled by the infant formula manufacturers to better approximate its composition to HM. However, certain components such as hormones, living cells, immunoglobulins, enzymes and cellular messengers are not and cannot be added to these products. ${ }^{39}$

Table 3. Fatty acid (FA) composition of human milk (HM), human whey (HW) and five different infant formulas

\begin{tabular}{lccccccc}
\hline FA composition & HW & HM & Infant formula 1 & Infant formula 2 & Infant formula 3 & Infant formula 4 & Infant formula 5 \\
\hline $18: 2 \mathrm{n}-6$ (LA) / \% & $9.85 \pm 0.13^{\mathrm{b}}$ & $20.25 \pm 0.04^{\mathrm{a}}$ & $18.15 \pm 0.02$ & $17.93 \pm 0.03$ & $17.38 \pm 0.03$ & $20.00 \pm 0.03$ & $22.27 \pm 0.08$ \\
$18: 3 \mathrm{n}-3$ (ALA) / \% & $0.31 \pm 0.01^{\mathrm{b}}$ & $1.08 \pm 0.03^{\mathrm{a}}$ & $1.51 \pm 0.05$ & $2.28 \pm 0.01$ & $2.17 \pm 0.00$ & $1.90 \pm 0.01$ & $2.51 \pm 0.01$ \\
$20: 4 \mathrm{n}-6$ (AA) / \% & $0.95 \pm 0.11^{\mathrm{a}}$ & $0.06 \pm 0.02^{\mathrm{b}}$ & $0.66 \pm 0.00$ & $0.37 \pm 0.00$ & $0.37 \pm 0.00$ & $0.18 \pm 0.01$ & $0.39 \pm 0.00$ \\
$20: 5 \mathrm{n}-3$ (EPA) / \% & $0.36 \pm 0.07^{\mathrm{a}}$ & $0.04 \pm 0.00^{\mathrm{b}}$ & $0.06 \pm 0.05$ & $0.06 \pm 0.05$ & $0.18 \pm 0.16$ & - & $0.04 \pm 0.07$ \\
$22: 6 \mathrm{n}-3$ (DHA) $\%$ & $0.37 \pm 0.06^{\mathrm{a}}$ & $0.16 \pm 0.02^{\mathrm{b}}$ & $0.31 \pm 0.01$ & $0.32 \pm 0.00$ & $0.33 \pm 0.00$ & $0.09 \pm 0.03$ & $0.24 \pm 0.00$ \\
\hline
\end{tabular}

Results expressed as mean \pm standard deviation (SD) of triplicate. Values with different letters on the same line are significantly different $(p<0.05)$ by the Tukey's test. LA: linoleic acid; ALA: alpha linolenic acid; AA: arachidonic acid; EPA: eicosapentaenoic acid; DHA: docosahexaenoic acid. 


\section{Nutritional lipid quality}

Figure 2 and Table 4 present the results of the nutritional quality indices for human milk (HM) and human whey (HW). The analysis was performed with the aim of attesting the lipid nutritional quality and comparing it with the HM sample, so in this way, it is possible to observe whether the product developed has an adequate lipid nutritional quality.

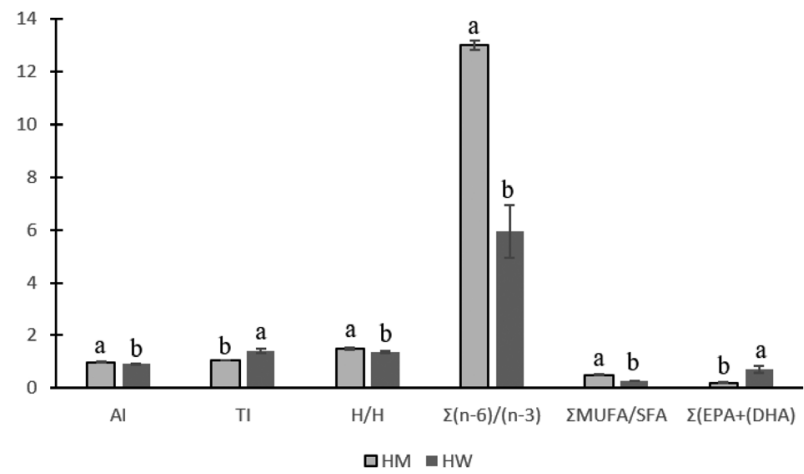

Figure 2. Indices of lipid nutritional quality of human milk (HM) and human whey (HW). AI: atherogenicity index; TI: thrombogenicity index; $\mathrm{H} / \mathrm{H}$ : proportion of fatty acids hypocholesterolemic/hypercholesterolemic; $\Sigma(n-6) /(n-3)$ : sum of the omega-6 family due to the omega-3; $\Sigma$ MUFA/SFA: sum of polyunsaturated fatty acids due to saturated fatty acids; $\Sigma(\mathrm{EPA})+(\mathrm{DHA})$ : sum of eicosapentaenoic and docosahexaenoic fatty acids; HM: human milk; HW: human whey. Results expressed as mean \pm standard deviation $(\mathrm{SD})$ of triplicate. Values with different letters on the same line are significantly different $(p<0.05)$ by the Tukey's test.

Table 4. Indices of lipid nutritional quality of human milk (HM) and human whey (HW)

\begin{tabular}{lcc}
\hline Indice & HM & HW \\
\hline AI & $0.98 \pm 0.02^{\mathrm{a}}$ & $0.91 \pm 0.01^{\mathrm{b}}$ \\
TI & $1.07 \pm 0.01^{\mathrm{b}}$ & $1.41 \pm 0.09^{\mathrm{a}}$ \\
$\mathrm{H} / \mathrm{H}$ & $1.51 \pm 0.04^{\mathrm{a}}$ & $1.35 \pm 0.04^{\mathrm{b}}$ \\
$\Sigma(\mathrm{n}-6) /(\mathrm{n}-3)$ & $13.01 \pm 0.17^{\mathrm{a}}$ & $5.95 \pm 1.02^{\mathrm{b}}$ \\
$\Sigma$ MUFA/SFA & $0.51 \pm 0.01^{\mathrm{a}}$ & $0.28 \pm 0.01^{\mathrm{b}}$ \\
$\Sigma($ EPA $)+($ DHA $)$ & $0.20 \pm 0.02^{\mathrm{b}}$ & $0.73 \pm 0.13^{\mathrm{a}}$ \\
\hline
\end{tabular}

Results expressed as mean \pm standard deviation (SD) of triplicate. Values with different letters on the same line are significantly different $(p<0.05)$ by the Tukey's test. AI: atherogenicity index; TI: thrombogenicity index; $\mathrm{H} / \mathrm{H}$ : FAs proportion of fatty acids (FAs) hypocholesterolemic/ hypercholesterolemic; $\Sigma(n-6) /(n-3)$ : sum of the omega- 6 family due to the omega-3; ( MUFA/SFA): sum of polyunsaturated fatty acids due to saturated fatty acids; $\Sigma(\mathrm{EPA})+(\mathrm{DHA})$ : sum of eicosapentaenoic and docosahexaenoic fatty acids; SFA: saturated fatty acids; MUFA: monounsaturated fatty acids; EPA: eicosapentaenoic acid; DHA: docosahexaenoic acid.

The analysis was performed with the aim of attesting the lipid nutritional quality and comparing it with the HM sample, so in this way, it is possible to observe whether the product developed has an adequate lipid nutritional quality.

The atherogenicity index (AI) revealed a significant difference compared to the Tukey's test $(p<0.05)$. HM sample presented the highest value $(0.98 \pm 0.02)$, while
HW sample presented the value of $0.91 \pm 0.01$. This is due to the fact that in HW samples the values of $\Sigma$ MUFA and n-3 are higher in comparison to the HM samples. The 12:0 and 14:0 concentrations were also higher in the HM sample than in the HW sample, which corroborates with the result.

The thrombogenicity index (TI) was statistically different by the Tukey's test $(p<0.05)$; behavior similar to AI analysis. The highest value obtained was for $\mathrm{HW}$ $(1.41 \pm 0.09)$ sample and the lowest for HM $(1.07 \pm 0.01)$ sample. There are no reference values in the literature for AI and TI, however, according to Ulbricht and Southgate ${ }^{18}$ and Santos-Silva et al., ${ }^{17}$ these indices indicate potential platelet aggregation, consequently, low levels are desirable, as both indices indicate the quality of the lipid diet and its potential effects on the development of coronary diseases.

The proportion of hypocholesterolemic/ hypercholesterolemic $(\mathrm{H} / \mathrm{H})$ FAs revealed a significant difference between samples. The highest value found was for the HM sample $(1.51 \pm 0.04)$ and the lowest value found was for the HW $(1.35 \pm 0.04)$ sample. According to Santos-Silva et al.,${ }^{17}$ the proportionality of $\mathrm{H} / \mathrm{H}$ indicates the specific effects of FA on cholesterol metabolism, values above 2.0 are desirable, since it leads to greater health benefits, since hypocholesterolemic FAs act to reduce low density lipoprotein (LDL), which prevents cardiovascular disease. Hypercholesterolemic FA increases the blood cholesterol level, which can increase the risks of coronary heart disease. Considering Table 4, it is stated that the values found are below 2.0 for all samples, due to the $\Sigma$ SFA being superior to the $\Sigma$ PUFA, both related to the maternal diet.

$\Sigma$ n-6 to $\Sigma$ n-3 ratio revealed a statistical difference. Simopoulos ${ }^{48}$ reports that the acceptable proportion for the proper functioning of the organism is between 5 and 10. The HM sample obtained the highest value $(13.01 \pm 0.17)$, outside the acceptable proportion, while the HW sample presented values within the indicated parameter $(5.95 \pm 1.02)$. This relationship is important because these FAs compete for the metabolic pathways of elongation and desaturation. The values found in the $\mathrm{HM}$ are above the recommended, because the $\Sigma \mathrm{n}-6$ is ten to twenty times higher than the $\Sigma \mathrm{n}-3$; it is significance to mention that the reason why $\Sigma \mathrm{n}-6$ is high probably comes from the maternal diet, poor in the consumption of foods rich in n-3, characteristic of Western diets.

PUFA/SFA ratio revealed statistical differences, HM samples presented the highest value $(0.51 \pm 0.01)$ and HW samples presented the lowest $(0.28 \pm 0.01)$ values. According to the literature, ${ }^{49}$ foods with a PUFA/SFA ratio below 0.45 were considered unhealthy due to its potential to induce an increase in blood cholesterol; only the HM sample presented values above the mentioned value. 
The $\Sigma(\mathrm{EPA})+(\mathrm{DHA})$ revealed statistical differences, however the highest value of the sum corresponds to the highest value of the HW $(0.73 \pm 0.13)$ sample and the lowest value of the HM sample $(0.20 \pm 0.02)$. The World Health Organization (WHO) $)^{50}$ and the United Nations Food and Agriculture Organization (FAO $)^{14}$ recommend a daily intake of $250 \mathrm{mg}$ of each FAs, in order to prevent coronary heart disease and inflammatory processes. As a result, both samples did not show the recommended values for daily intake of EPA and DHA. However, the presence of both FAs in the samples is extremely important, because its consumption would have a participation in the intake of EPA + DHA.
Long-chain n-3 PUFAs exhibit anti-inflammatory properties and can modulate immune function. Therefore, circulating DHA levels are associated with neurological, visual and intelligence quotient (IQ) performance. ${ }^{38,50}$

\section{Triacylglycerol (TAG) determination}

The TAG determination results performed by direct infusion in ESI-MS are described in Figure 3 and Table 5. The most intense ion spectral peak was present between $\mathrm{m} / \mathrm{z} 876$ and 877 . This analysis is important to identify TAGs present in HM and HW samples, and compare its

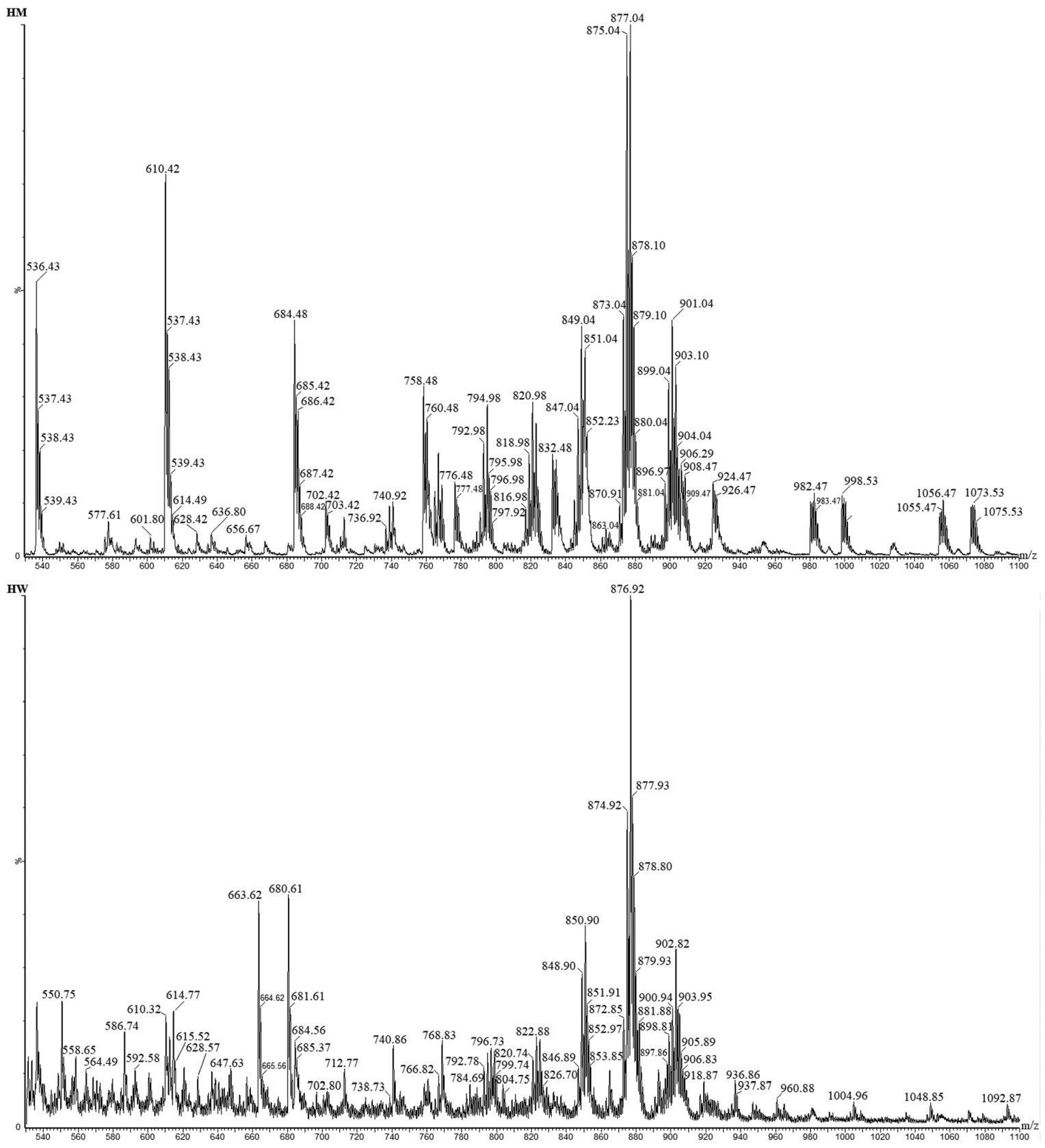

Figure 3. Ion spectrum of $\left[\mathrm{TAG}+\mathrm{NH}_{4}\right]^{+}$human milk (HM) and human whey (HW) from ESI(+)-MS. 
correlation. Figure 3 shows pooled human milk (HM) and human whey (HW) spectra obtained by this analysis in the $\mathrm{m} / \mathrm{z}$ range from 530 to 1100 .

According to the Lipid maps ${ }^{\circledast}$ database, in the $m / z$ region 530-791 diacylglycerols (DAG) and monoacylglycerols (MAG) are presented, and in the $\mathrm{m} / \mathrm{z}$ region 792-916 triacylglycerols (TAG) are found. The TAG with the highest ionic intensity in the spectral peak was $\left[\mathrm{TAG}+\mathrm{NH}_{4}\right]^{+}$ POO with $m / z$ 877, which corroborates with the research by Rydlewski et al. ${ }^{29}$ who found the same result for the HM analysis. In the HM spectrum, the ionic peaks are more intense compared to HW samples, since the lipids percentage in the HM sample is higher $(3.23 \pm 0.13)$ in comparison to the HW sample $(0.93 \pm 0.13)$.

Table 5 presents the 21 highest $\mathrm{m} / \mathrm{z}$, ratios, with its respective TAGs, found in the region between $\mathrm{m} / \mathrm{z}, 792$ to 916. The LAMES Platform was used; it was developed for the random TAGs configuration for vegetable oils, ${ }^{20}$ but it can also be used for animal tissues. However, for HM the order of FAs in the TAG (Sn-1, Sn-2, Sn-3) is not in accordance with the literature, since palmitic acid (16:0) for this matrix (HM) is mostly in the Sn-2 position, nevertheless this fact does not interfere with the final result of this work. ${ }^{51-53}$
Comparing the results obtained by the FA composition (Table 2), with the TAGs presented in Table 5, it was possible to observe the frequency of oleic $(\mathrm{O}, 18: 1 \mathrm{n}-9)$ and palmitic (P, 16:0) acids in the TAGs, which are the ones with the highest concentrations in relation to FAs, results similar to the studies by Manin et al. ${ }^{32}$ and Rydlewski et al. ${ }^{29}$

The highest estimates in the TAGs percentage are present in $\mathrm{m} / \mathrm{z} 874$ [TAG $\left.+\mathrm{NH}_{4}\right]^{+}$PLO with values of $\mathrm{HM}(13.026)$ and $\mathrm{HW}(9.305), \mathrm{m} / z 877\left[\mathrm{TAG}+\mathrm{NH}_{4}\right]^{+}$ POO of HM (10.042) and HW (15.334), $\mathrm{m} / \mathrm{z} 900$ $\left[\mathrm{TAG}+\mathrm{NH}_{4}\right]^{+} \mathrm{OLO}$ of HM (9.183) and HW (5.348), $m / z 850\left[\mathrm{TAG}+\mathrm{NH}_{4}\right]^{+}$POP of HM (7.123) and HW (13.340), $\mathrm{m} / z 902\left[\mathrm{TAG}+\mathrm{NH}_{4}\right]^{+} \mathrm{OOO}$ of $\mathrm{HM}(4.720)$ and HW (5.875), $\mathrm{m} / z 848$ [TAG $\left.+\mathrm{NH}_{4}\right]^{+}$PLP of HM (4.620) and HW (4.047). Similar results to most TAGs found in the study by Manin et al., ${ }^{32}$ who analyzed pasteurized and lyophilized HM during six months of storage.

Comparing the samples of raw HM of the mature phase before ultracentrifugation to obtain HW, five TAGs were observed, that do not appear in Table 5 for the HM sample. Although it appears for $\mathrm{HW}\left(\left[\mathrm{TAG}+\mathrm{NH}_{4}\right]^{+} \mathrm{SPP}, \mathrm{PVcO}\right.$, SPS, SOS, BhOP). This is due to its percentage below $1 \%$

Table 5. Estimation of TAG ions determined by ESI(+)-MS of human milk (HM) and human whey (HW) defined by the LAMES platform

\begin{tabular}{|c|c|c|c|c|c|c|}
\hline \multirow{2}{*}{ Molecular formula } & \multirow{2}{*}{ Shorthand } & \multirow{2}{*}{ Ionization } & \multirow{2}{*}{$m / z$} & \multirow{2}{*}{ TAG assignment } & \multicolumn{2}{|c|}{ TAG estimate $/ \%$} \\
\hline & & & & & HM & HW \\
\hline$\overline{\mathrm{C}_{49} \mathrm{H}_{90} \mathrm{O}_{6}}$ & $46: 2$ & {$\left[\mathrm{M}+\mathrm{NH}_{4}\right]^{+}$} & 792 & LaLP & 2.663 & - \\
\hline $\mathrm{C}_{49} \mathrm{H}_{92} \mathrm{O}_{6}$ & $46: 1$ & {$\left[\mathrm{M}+\mathrm{NH}_{4}\right]^{+}$} & 794 & $\mathrm{LaOP}$ & 4.107 & 1.804 \\
\hline $\mathrm{C}_{51} \mathrm{H}_{92} \mathrm{O}_{6}$ & $48: 3$ & {$\left[\mathrm{M}+\mathrm{NH}_{4}\right]^{+}$} & 818 & LaLO & 3.755 & - \\
\hline $\mathrm{C}_{51} \mathrm{H}_{94} \mathrm{O}_{6}$ & $48: 2$ & {$\left[\mathrm{M}+\mathrm{NH}_{4}\right]^{+}$} & 820 & $\mathrm{LaOO}$ & 2.895 & - \\
\hline $\mathrm{C}_{51} \mathrm{H}_{94} \mathrm{O}_{6}$ & $48: 2$ & {$\left[\mathrm{M}+\mathrm{NH}_{4}\right]^{+}$} & 820 & MLP & 2.788 & - \\
\hline $\mathrm{C}_{51} \mathrm{H}_{96} \mathrm{O}_{6}$ & $48: 1$ & {$\left[\mathrm{M}+\mathrm{NH}_{4}\right]^{+}$} & 822 & MOP & 4.299 & 3.798 \\
\hline $\mathrm{C}_{51} \mathrm{H}_{98} \mathrm{O}_{6}$ & $48: 0$ & {$\left[\mathrm{M}+\mathrm{NH}_{4}\right]^{+}$} & 824 & PPP & 1.684 & 3.868 \\
\hline $\mathrm{C}_{53} \mathrm{H}_{96} \mathrm{O}_{6}$ & $50: 3$ & {$\left[\mathrm{M}+\mathrm{NH}_{4}\right]^{+}$} & 846 & MLO & 3.931 & - \\
\hline $\mathrm{C}_{53} \mathrm{H}_{98} \mathrm{O}_{6}$ & $50: 2$ & {$\left[\mathrm{M}+\mathrm{NH}_{4}\right]^{+}$} & 848 & PLP & 4.620 & 4.047 \\
\hline $\mathrm{C}_{53} \mathrm{H}_{98} \mathrm{O}_{6}$ & $50: 2$ & {$\left[\mathrm{M}+\mathrm{NH}_{4}\right]^{+}$} & 848 & MOO & 3.031 & 2.183 \\
\hline $\mathrm{C}_{53} \mathrm{H}_{100} \mathrm{O}_{6}$ & $50: 1$ & {$\left[\mathrm{M}+\mathrm{NH}_{4}\right]^{+}$} & 850 & POP & 7.123 & 13.340 \\
\hline $\mathrm{C}_{53} \mathrm{H}_{102} \mathrm{O}_{6}$ & $50: 0$ & {$\left[\mathrm{M}+\mathrm{NH}_{4}\right]^{+}$} & 852 & SPP & - & 4.502 \\
\hline $\mathrm{C}_{55} \mathrm{H}_{98} \mathrm{O}_{6}$ & $52: 4$ & {$\left[\mathrm{M}+\mathrm{NH}_{4}\right]^{+}$} & 872 & PLL & 4.224 & - \\
\hline $\mathrm{C}_{55} \mathrm{H}_{100} \mathrm{O}_{6}$ & $52: 3$ & {$\left[\mathrm{M}+\mathrm{NH}_{4}\right]^{+}$} & 874 & PLO & 13.026 & 9.305 \\
\hline $\mathrm{C}_{55} \mathrm{H}_{100} \mathrm{O}_{6}$ & $52: 3$ & {$\left[\mathrm{M}+\mathrm{NH}_{4}\right]^{+}$} & 874 & $\mathrm{PVcO}$ & - & 1.899 \\
\hline $\mathrm{C}_{55} \mathrm{H}_{104} \mathrm{O}_{6}$ & $52: 2$ & {$\left[\mathrm{M}+\mathrm{NH}_{4}\right]^{+}$} & 877 & $\mathrm{POO}$ & 10.042 & 15.334 \\
\hline $\mathrm{C}_{55} \mathrm{H}_{104} \mathrm{O}_{6}$ & $52: 2$ & {$\left[\mathrm{M}+\mathrm{NH}_{4}\right]^{+}$} & 877 & SLP & 2.372 & 3.140 \\
\hline $\mathrm{C}_{55} \mathrm{H}_{104} \mathrm{O}_{6}$ & $52: 1$ & {$\left[\mathrm{M}+\mathrm{NH}_{4}\right]^{+}$} & 878 & SOP & 3.658 & 10.349 \\
\hline $\mathrm{C}_{55} \mathrm{H}_{106} \mathrm{O}_{6}$ & $52: 0$ & {$\left[\mathrm{M}+\mathrm{NH}_{4}\right]^{+}$} & 880 & SPS & - & 1.746 \\
\hline $\mathrm{C}_{57} \mathrm{H}_{86} \mathrm{O}_{6}$ & $54: 1$ & {$\left[\mathrm{M}+\mathrm{NH}_{4}\right]^{+}$} & 884 & SOS & - & 2.007 \\
\hline $\mathrm{C}_{57} \mathrm{H}_{100} \mathrm{O}_{6}$ & $54: 5$ & {$\left[\mathrm{M}+\mathrm{NH}_{4}\right]^{+}$} & 898 & OLL & 5.956 & - \\
\hline $\mathrm{C}_{57} \mathrm{H}_{103} \mathrm{O}_{6}$ & $54: 4$ & {$\left[\mathrm{M}+\mathrm{NH}_{4}\right]^{+}$} & 900 & OLO & 9.183 & 5.348 \\
\hline $\mathrm{C}_{57} \mathrm{H}_{104} \mathrm{O}_{6}$ & $54: 3$ & {$\left[\mathrm{M}+\mathrm{NH}_{4}\right]^{+}$} & 902 & $\mathrm{OOO}$ & 4.720 & 5.875 \\
\hline $\mathrm{C}_{57} \mathrm{H}_{104} \mathrm{O}_{6}$ & $54: 3$ & {$\left[\mathrm{M}+\mathrm{NH}_{4}\right]^{+}$} & 902 & SLO & 3.345 & 3.609 \\
\hline $\mathrm{C}_{57} \mathrm{H}_{106} \mathrm{O}_{6}$ & $54: 2$ & {$\left[\mathrm{M}+\mathrm{NH}_{4}\right]^{+}$} & 904 & $\mathrm{SOO}$ & 2.578 & 5.948 \\
\hline $\mathrm{C}_{59} \mathrm{H}_{94} \mathrm{O}_{6}$ & $56: 1$ & {$\left[\mathrm{M}+\mathrm{NH}_{4}\right]^{+}$} & 916 & BhOP & - & 1.899 \\
\hline
\end{tabular}

La: lauric acid (12:0); M: myristic acid (14:0); P: palmitic acid (16:0); S: stearic acid (18:0); O: oleic acid (18 1n-9); Vc: vaccenic acid (18:1n-7); L: linoleic acid (18:2n-6); Bh: docosanoic acid (22:0). 
in the HM sample, a factor used to select the main TAGs in the LAMES Platform.

The TAGs percentage in the HW sample in relation to the HM sample varied due to its distribution in the fat globules, as the ultracentrifugation was performed, those present in casein decreased its percentage $\left[\mathrm{TAG}+\mathrm{NH}_{4}\right]^{+} \mathrm{LaOP}$, MOP, PLP, MOO, PLO and OLO. While those associated with albumin, whey soluble fraction $\left(\left[\mathrm{TAG}+\mathrm{NH}_{4}\right]^{+} \mathrm{PPP}\right.$, POP, SPP, PVcO, POO, SLP, SOP, SPS, SOS, OOO, SLO, $\mathrm{SOO}, \mathrm{BhOP}$ ) displayed a high percentage, this is justified because the lipids that remained in the liquid fraction had its percentage rebalanced.

According to Mazzocchi et al., ${ }^{38}$ TAGs with SFA and MUFA are rapidly hydrolyzed by gastrointestinal lipases, without the need of bile salts, which makes its products more easily absorbed and taken to the liver, process that assists in the infants' digestion process. These characteristics are present in HW compared to HM.

\section{Conclusions}

From the above, it can be concluded that it was possible to obtain a co-product of human milk (HM) discarded by human milk banks; the human whey (HW). For its characterization, analyzes of proximate composition, fatty acid (FA) composition, assessment of the nutritional lipids quality, as well as the triacylglycerols (TAG) profile were performed. The results obtained revealed that the chemical composition underwent significant modifications since the HW was obtained from the HM, except for the percentage of ash and carbohydrates. As for the fatty acids composition, it was observed that strictly essential FAs, essential FAs, and other FAs found in HM, remained present in HW, being extremely important, as these FAs are responsible for several health benefits of infants.

As for to the lipid nutritional quality, both the atherogenicity and the thrombogenicity indices displayed adequate values for both samples, which indicates a lipidic food quality and its potential effects on the development of coronary diseases. Finally, the triacylglycerols profile exhibited variation in the samples analyzed, with a higher percentage of saturated and monounsaturated FAs, which is important, as it assists in the digestion process. Therefore, HW has potential for application in isolated form and to be used applied in other foods.

\section{Acknowledgments}

The authors would like to thank the Conselho Nacional de Desenvolvimento Científico e Tecnológico (CNPq), Coordenação de Aperfeiçoamento de Pessoal de Nível
Superior (CAPES) for financial assistance, to the research group APLE-A; and to the Human Milk Bank of University Hospital of Maringá for its partnership and donation of human milk samples.

\section{Author Contributions}

Eloize S. Alves was responsible for formal analysis, data curation, writing-original draft, conceptualization; Matheus C. Castro for formal analysis, writing-original draft, conceptualization; Bruno H. F. Saquetti for formal analysis, investigation; Luciana P. Manin for data curation, visualization; Roberta da Silveira for review and editing, visualization; Patricia M. Souza for formal analysis, investigation; Oscar O. Santos for conceptualization, supervision; Jesuí V. Visentainer for funding acquisition, supervision.

\section{References}

1. Franklin, P.; Volk, A. A. In Encyclopedia of Evolutionary Psychological Science; Shackelford, T. K.; Weekes-Shackelford, V. A., eds; Springer: Cham, 2019, p. 36.

2. Johnston, M.; Landers, S.; Noble, L.; Szucs, K.; Viehmanm, L.; J. Pediatr. 2012, 129, e827.

3. Agência Nacional de Vigilância Sanitária (ANVISA); Banco de Leite Humano: Funcionamento, Prevenção e Controle de Risco, $1^{\text {st }}$ ed.; ANVISA: Brasília, 2008. Available at https:// www.anvisa.gov.br/servicosaude/manuais/manual_banco_leite. pdf, accessed in June 2021.

4. Borges, M. S.; Oliveira, A. M. M.; Hattori, W. T.; Abdallah, V. O. S.; J. Pediatr. 2018, 94, 399.

5. Agência Nacional de Vigilância Sanitária (ANVISA); Resolução da Diretoria Colegiada (RDC) No. 222, de 28 de março de 2018, Regulamenta as Boas Práticas de Gerenciamento dos Resíduos de Serviços de Saúde e Dá outras Providências; Diário Oficial da União (DOU), Brasília, No. 61, de 29/03/2018, p. 76, available at http://bvsms.saude.gov.br/bvs/saudelegis/ anvisa/2018/rdc0222_28_03_2018.pdf, accessed in June 2021.

6. Grazziotin, A. L.; Grazziotin, M. C. B.; Letti, L. A. J.; J. Pediatr. 2010, 86, 290.

7. Rede Brasileira de Bancos de Leite Humano; Gestão: Relatórios de Produção; Fundação Oswaldo Cruz, 2020. Available at https://producao.redeblh.icict.fiocruz.br/portal_blh/blh_brasil. php, accessed on September 06, 2020.

8. Guo, M.; Whey Protein Production, Chemistry, Functionality, and Applications, $1^{\text {st }}$ ed.; John Wiley \& Sons: Hoboken, USA, 2019.

9. Silva, R. C.; Escobedo, J. P.; Gioielli, L. A.; Quintal, V. S.; Ibidi, S. M.; Albuquerque, E. M.; Quim. Nova 2007, 30, 1535.

10. Lu, J.; Zhang, S.; Liu, L.; Pang, X.; Ma, C.; Jiang, S.; Lv, J.; Food Chem. 2018, 261, 274. 
11. Gomes-Santos, A. C.; Fonseca, R. C.; Lemos, L.; Reis, D. S.; Moreira, T. G.; Souza, A. L.; Silva, M. R.; Silvestre, M. P.; Cara, D. C.; Faria, A. M.; Cell. Immunol. 2015, 298, 47.

12. Association of Official Analytical Chemists (AOAC); Official Methods of Analysis of the Association of Official Analytical Chemists, $18^{\text {th }}$ ed.; AOAC: Gaithersburg, 2005.

13. Folch, J.; Lees, M.; Sloane Stanley, G. H. A.; J. Biol. Chem. 1957, 226, 497.

14. Food and Agriculture Organization (FAO); Food Energy Methods of Analysis and Conversion Factors, $77^{\text {th }}$ ed.; FAO: Rome, 2003, available at http://www.fao.org/3/y5022e/ y5022e00.htm\#Contents, accessed in June 2021.

15. ISO 12966: Animal and Vegetable Fats and Oils - Gas Chromatography of Fatty Acid Methyl Esters - Part 2: Preparation of Methyl Esters of Fatty Acids, ISO: Geneva, 2017.

16. Simionato, J. I.; Garcia, J. C.; dos Santos, G. T.; Oliveira, C. C.; Visentainer, J. V.; de Souza, N. E.; J. Braz. Chem. Soc. 2010, 21,520 .

17. Santos-Silva, J.; Bessa, R. J. B.; Santos-Silva, F.; Livest. Prod. Sci. 2002, 77, 187.

18. Ulbricht, T. L. V.; Southgate, D. A. T.; Lancet 1991, 338, 985.

19. da Silveira, R.; Vágula, J. M.; de Lima Figueiredo, I.; Claus, T.; Galuch, M. B.; Santos Jr., O. O.; Visentainer, J. V.; Food Res. Int. 2017, 102, 43.

20. Antoniosi Filho, N. R.; Mendes, O. L.; Lanças, F. M.; J. Chromatogr. 1995, 40, 557.

21. Silva, F. A. S.; The ASSISTAT Software: Statistical Assistance; Universidade Federal de Campina Grande, Brazil, 1996.

22. Jauregi, P.; Welderufael, F. T.; Nutrafoods 2010, 9, 13.

23. Leite, J. A.; Migotto, A. M.; Landgraf, M.; Quintal, V. S.; Gut, J. A.; Tadini, C. C.; LWT-Food Sci. Technol. 2019, 115, 108466.

24. Shi, Y. D.; Sun, G. Q.; Zhang, Z. G.; Deng, X.; Kang, X. H.; Liu, Z. D.; Sheng, Q. H.; Food Chem. 2011, 127, 1193.

25. Lamichhane, P.; Sharma, P.; Kelly, A. L.; Risbo, J.; Rattray, F. P.; Sheehan, J. J.; Food Chem. 2021, 336, 127625.

26. Cecchi, H. M.; Fundamentos Teóricos e Práticos em Análise de Alimentos, $2^{\text {nd }}$ ed.; Editora Unicamp: Campinas, Brazil, 2003.

27. Bruxel, R.; Sica, C. D. A.; RBONE 2019, 13, 194.

28. Erliana, U. D.; Fly, A. D.; Nutrients 2019, 11, 1284.

29. Rydlewski, A. A.; Silva, P. D.; Manin, L. P.; Tavares, C. B. G.; Paula, M. G.; Figueiredo, I. L.; Neia, V. B. M. J. C.; Santos, O. O.; Visentainer, J. V.; J. Braz. Chem. Soc. 2019, 30, 1063.

30. Agência Nacional de Vigilância Sanitária (ANVISA); Resolução da Diretoria Colegiada (RDC) No. 171, de 4 de setembro de 2006, Dispõe sobre Regulamento Técnico para o Funcionamento de Bancos de Leite Humano; Diário Oficial da União (DOU), Brasília, No. 171, 2006, p. 33. Available at https://bvsms.saude.gov.br/bvs/saudelegis/anvisa/2006/ res0171_04_09_2006.html, accessed in June 2021.

31. Demmelmair, H.; Koletzko, B.; Best Pract. Res. Clin. Endocrinol. Metab. 2018, 32, 57.
32. Manin, L. P.; Rydlewski, A. A.; Galuch, M. B.; Pizzo, J. S.; Zappielo, C. D.; Senes, C. E. R.; Santos, O. O.; Visentainer, J. V.; J. Braz. Chem. Soc. 2019, 30, 1579.

33. Costa, A. G. V.; Sabarense, C. M.; Rev. Nutr. 2010, 23, 445.

34. Rydlewski, A. A.; Pizzo, J. S.; Manin, L. P.; Zappielo, C. D.; Galuch, M. B.; Santos, O. O.; Visentainer, J. V.; Rev. Virtual Quim. 2020, 12, 155.

35. Mehrotra, V.; Sehgal, S. K.; Bangale, N. R.; Clin. Epidemiol. Global Health 2019, 7, 153.

36. Yehuda, S.; Rabinovitz, S.; Carasso, R. L.; Mostofsky, D. I.; Neurobiol. Aging 2002, 23, 843.

37. Perini, J. Â. D. L.; Stevanato, F. B.; Sargi, S. C.; Visentainer, J. E. L.; Dalalio, M. M. D. O.; Matshushita, M.; Souza, N. E. D.; Visentainer, J. V.; Rev. Nutr. 2010, 23, 1075.

38. Mazzocchi, A.; D’Oria, V.; de Cosmi, V.; Bettocchi, S.; Milani, G. P.; Silano, M.; Agostoni, C.; Nutrients 2018, 10, 567.

39. Barreiro, R.; Regal, P.; Díaz-Bao, M.; Fente, C. A.; Cepeda, A.; Foods 2015, 4, 605.

40. Rodriguez-Santana, Y.; Ochoa, J. J.; Lara-Villoslada, F.; Kajarabille, N.; Saavedra-Santana, P.; Hurtado, J. A.; Peña, M.; Diaz-Castro, J.; Sebastian-Garcia, I.; Machin-Martin, E.; Villanueva, M.; Ramirez-Garcia, O.; Peña-Quintana, L.; Prostaglandins, Leukotrienes Essent. Fatty Acids 2017, 126, 32.

41. Martin, C. R.; Ling, P.; Blackburn, G. L.; Nutrients 2016, 8, 279.

42. Sun, C.; Wei, W.; Su, H.; Zou, X.; Wang, X.; Food Chem. 2018, $242,36$.

43. Sun, C.; Zou, X. Q.; Yao, Y. P.; Jin, J.; Xia, Y.; Huang, J. H.; Jin, Q.; Wang, X.; Int. Dairy J. 2016, 63, 51.

44. Zou, X.; Huang, J.; Jin, Q.; Guo, Z.; Liu, Y.; Cheong, L.; Xu, X.; Wang, X.; J. Agric. Food Chem. 2013, 61, 7070.

45. Sun, C.; Wei, W.; Zou, X.; Huang, J.; Jin, Q.; Wang, X.; Food Chem. 2018, 252, 162.

46. Barreiro, R.; Regal, P.; Lopez-Racamonde, O.; Cepeda, A.; Fente, C. A.; J. Physiol. Biochem. 2017, 74, 138.

47. Tu, A.; Ma, Q.; Bai, H.; Du, Z.; Food Chem. 2017, 221, 567.

48. Simopoulos, A. P.; Food Rev. Int. 2004, 20, 77.

49. Levy, L.; Alison, T.; Healthcare 2017, 5, 9.

50. World Health Organization (WHO); Global Strategy on Diet, Physical Activity and Health: Diet, Nutrition and the Prevention of Chronic Diseases, No. 916, 2003, available at https://www.who.int/dietphysicalactivity/publications/trs916/ en/gsfao_overall.pdf?ua=1, accessed on July 28, 2020.

51. Hahn-Holbrook, J.; Fish, A.; Glynn, L. M.; Nutrients 2019, 11, 2964.

52. Koletzko, B.; Ann. Nutr. Metab. 2016, 69, 843.

53. Carta, G.; Murru, E.; Lisai, S.; Sirigu, A.; Piras, A.; Collu, M.; Batetta, B.; Gambelli, L.; Banni, S.; PLoS One 2015, 10, e0120424.

Submitted: March 23, 2021

Published online: June 24, 2021 